OmniAkuatika, 12 (2): 38-46, 2016
ISSN: 1858-3873 print / 2476-9347 online
Research Article

\title{
Kajian Aspek Populasi Menggunakan Model Pertumbuhan Allometri Spesies Kerang Kapah di Pantai Binalatung Kota Tarakan
}

\author{
Firman $^{1)}$, Gazali Salim ${ }^{2, *}$ \\ (1) Jurusan Manajemen Sumberdaya Perairan \\ (2) Jurusan Manajemen Sumberdaya Perairan \\ FPIK Universitas Borneo Tarakan (UBT) Kampus Pantai Amal Gedung E, \\ Jl. Amal Lama No.1,Po. Box. 170 Tarakan KAL-TARA. ${ }^{(2)}$ HP.081346583552 \\ *Corresponding author : axza_oke@yahoo.com
}

Received 3 Julie 2016; Accepted 10 October 2016; Available online 29 November 2016

\begin{abstract}
The research goal was to compare the shells types of Kapah (Meretrix meretrix; M. lyrata; Gelonia coaxans) that found in the Coast Binalatung area, Tarakan and to assess the growth of shellfish allometri. Sampling is done by making a transect along the coast Binalatung as much as 12 transects. Each transect arranged lengthwise along the beach with 25 meters of each transect. Sampling was carried out in the absence of repetition with an area of $25 \times 25$ meters transect. Sampling was done by using tools such as Kapah' rakes. The result showed the M. meretrix constistes of $63 \%$ of Kapah's population while M. lyrata and G. coaxans represent $27 \%$ and $10 \%$ respectively. Growth comparison between shell length and weight was considered as positive allometri while comparison between thick shells and weight of shellfish Kapah was allometri negative.
\end{abstract}

Keywords: shellfish kapah, allometri growth, Binalatung, Tarakan

\section{Pendahuluan}

Kota Tarakan memiliki potensi yang cukup tinggi bagi habitat biota aquatik kelas bivalvia yang hidup di daerah pantai berpasir dan berlumpur bagian timur kota Tarakan terutama di daerah Pantai Binalatung salah satunya dari spesies kerang kapah. Kerang kapah yang hidupnya di daerah pantai berpasir dan berlumpur Bianalatung ditemukan jenis spesies kerang kapah yaitu spesies $M$. meretrix, spesies $M$. lyrata dan spesies $G$. coaxans. Pendapat dari Salim dan Firdaus (2012) mengenai potensi $M$. meretrix di lihat dari segi protein memiliki kandungan protein sekitar $15,22 \%$ per 100 gram dan kandungan lemak sekitar 0,79\% per 100 gram, dan pendapat dari Salim dan Firdaus (2011) menyatakan bahwa $G$. coaxans di lihat dari segi protein didapatkan kandungan protein sebesar $15,33 \%$ dan kandungan lemak sebesar $0,69 \%$. Studi awal melalui wawancara terhadap pengepul pada tahun 2015 memiliki kisaran harga sebesar Rp. 45.000,00 tiap kilogramnya sedangkan hasil wawancara (2015) di Pasar Ghuser dan pasar Kampung Bugis memiliki kisaran harga spesies $G$. coaxans sebesar Rp. 25.00,00/kg.
Menurut Salim dan Firdaus (2012) menyatakan bahwa kerang kapah ( $M$. meretrix dan $M$. lyrata) di jadikan suatu ikon/ simbol kota Tarakan sebagai kuliner hidangan utama selain dari spesies ikan nomei (Harpodon nehereus) di kota Tarakan. Besarnya kebutuhan masyarakat dalam mengkonsumsi hidangan utama kuliner dari kerang kapah $(M$. meretrix dan $M$. lyrata) dapat berdampak terhadap penurunan populasi spesies tersebut di Pesisir Timur kota Tarakan. Hal ini di dukung dengan hasil wawancara terhadap pengepul Pantai Amal Lama kota Tarakan (2015) menyatakan bahwa keberadaan kerang kapah didaerah pantai amal saat ini jarang ditemukan populasinya baik jenis spesies $M$. meretrix ataupun $M$. lyrata, ada beberapa kerang kapah yang ditemukan namun ukurannya yang sangat kecil atau ukuran tersebut masih dalam tahapan pertumbuhan. Hasil wawancara dengan pengepul pantai Amal Lama Kota Tarakan (2015) menyatakan bahwa kerang kapah saat ini yang dijual berasal dari daerah lain yang memiliki populasi yang banyak seperti di pulau Keciak atau Tanjung Batu kota Tarakan.

Penelitian yang telah dilakukan mengenai kerang kapah di kota Tarakan yang dijadikan sebagai referensi pembanding 
mengenai pertumbuhan allometri kerang kapah yaitu Kajian Bioteknis mengenai potensi, pertumbuhan, indeks kondisi kerang kapah $(M$. meretrix) dari hasil tangkapan pengepul di Pantai Amal Lama Kota Tarakan (Salim dan Firdaus, 2012) ; Kajian Pertumbuhan Absolut dan Allometri Kerang kapah (M. meretrix) Yang Berasal dari Pengepul di Pantai Amal Lama Pulau Tarakan (Salim dan Firdaus, 2012) ; Pengukuran morfometri kerang kapah ( $M$. lyrata) Di PAntai Amal Lama Kota Tarakan (Herliantos et al, 2012) ; Analisis korelasi populasi biota endemic Kerang Kapah (G.coaxans) dan Vegetasi Mangrove di Kawasan Konservasi Mangrove dan Bekantan Kota Tarakan (Wiharyanto dan Salim, 2012) ; Namun demkian untuk Kajian Aspek Populasi Mengenai Model Pertumbuhan Allometri Spesies Kerang Kapah di daerah Pantai Binalatung Kota Tarakan, masih jarang dilakukan.

Tujuan penelitian yaitu untuk mengetahui persentase dari jumlah kerang kapah (M.meretrix, M.lyrata, G.coaxans) dan mengkaji mengenai pertumbuhan Allometri dari kerang kapah (M.meretrix, M.lyrata, G. coaxans) di Pantai Binalatung kota Tarakan.

\section{Metodologi}

\section{Waktu dan tempat}

Penelitian ini dilakukan selama 4 bulan dari bulan Desember 2014 hingga Maret 2015 meliputi persiapan penelitian, pengumpulan data, pengolahan data dan penyusunan laporan. Pengambilan sampel dilaksanakan pada tanggal 15 Februari sampai tanggal 5 Maret 2015, di daerah pantai Binalatung di Pantai Amal Tarakan Tengah Kota Tarakan. Waktu pengambilan sampel dilakukan pada saat kondisi air laut surut terendah.

\section{Alat dan bahan}

Alat yang digunakan yaitu alat tulis, GPS (Ground Position System), meteran, tali rapia, penggaruk Kapah, plastik sampel, oven, timbangan analitik, Alumunium foil, nampan, jangka sorong, kertas sampel, sendok, cool box, kamera digital.

Bahan yang digunakan pada penelitian ini adalah semua sampel kerang kapah yang ditemukan di daerah Pantai Binalatung.

\section{Metode penelitian}

Metode penelitian yang di gunakan dalam penelitian ini adalah metode penelitian deskriptif kuantatif dengan studi kasus.

\section{Prosedur penelitian}

\section{Penentuan lokasi tempat pengambilan sampel}

Penentuan lokasi menggunakan metode purposive sampling. Penentuan lokasi tempat pengambilan sampel dilakukan disepanjang pantai binalatung menggunakan metode transek sebanyak 12 kali, dimana pengambilan sampel di daerah tersebut diharapkan dapat mewakili habitat kerang kapah $M$. meretrix, $M$. lyrata dan $G$. coaxans pada kawasan pantai Binalatung Kota Tarakan.

\section{Desain penelitian}

Teknik pengumpulan data
menggunakan desain penelitian survey dan
skala laboratorium.
Pengambilan sampel kerang yang di
dapatkan langsung dari pantai Binalatung kota
Tarakan dengan menggunakan desain
penelitian survey, yang kemudian dianalisa
data dalam skala laboratorium dilakukan di
laboratorium Kualitas Air (KA) untuk proses
pengukuran dimensi cangkang (Panjang, tinggi
dan tebal) menggunakan jangka sorong
manual Biota diukur panjang cangkang, tinggi
cangkang, lebar cangkang dan berat kering
daging.

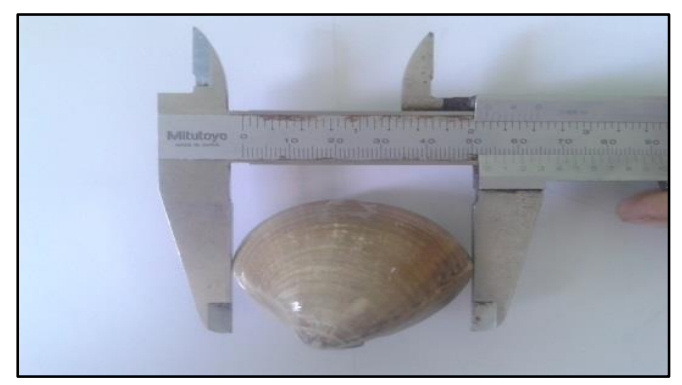

Gambar 1. Pengukuran panjang cangkang 


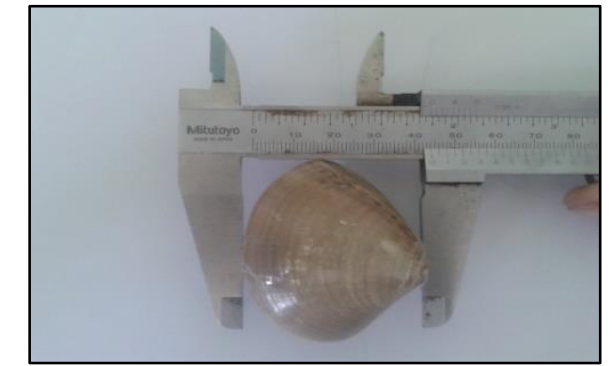

Gambar 2. Pengukuran tinggi cangkang

Panjang cangkang diukur dari bagian ujung posterior sampai ujung anterior. Panjang cangkang yang diukur merupakan panjang total dari kerang kapah (Gambar 1). Untuk mengukur tinggi cangkang diukur pada bagian dorsal ke bagian ventral cangkang (Gambar 2) dan untuk mengukur tebal cangkang diukur dari tepi cangkang bagian kiri ke tepi cangkang bagian kanan (Gambar 3). Kemudian dilakukan proses pembukaan cangkang dari kerang kapah dengan cara menurunkan suhu yaitu dengan cara memasukkan sampel kedalam cool box sehingga cangkang dari kerang kapah dapat terbuka agar dapat memudahkan daging dapat di ambil, yang dilanjutkan pengovenan untuk menghilangkan sisa-sisa air yang terkandung dalam daging kerang kapah sehingga di dapatkan berat kering dan untuk proses penimbangan

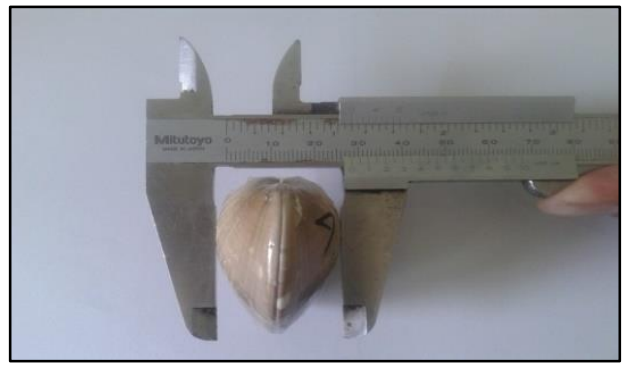

Gambar 3. Pengukuran tebal cangkang

menggunakan timbangan analitik di lakukan di Laboratorium Kualitas Air (KA), Fakultas Perikanan dan IImu Kelautan, Universitas Borneo Tarakan.

\section{Teknik pengambilan sampel}

Pengambilan sampel dilakukan dengan membuat transek disepanjang pantai binalatung sebanyak 12 transek. Setiap transek disusun memanjang di sepanjang pantai dengan jarak 25 meter dari setiap transek. Pengambilan sampel dilakukan tanpa adanya pengulangan dengan luas transek $25 \times 25$ meter (Gambar 4). Pengambilan sampel dilakukan dengan menggunakan alat bantu berupa penggaruk kapah. Sampel kerang yang ditemukan kemudian dimasukkan kedalam plastic sampel dan kemudian diberi label.

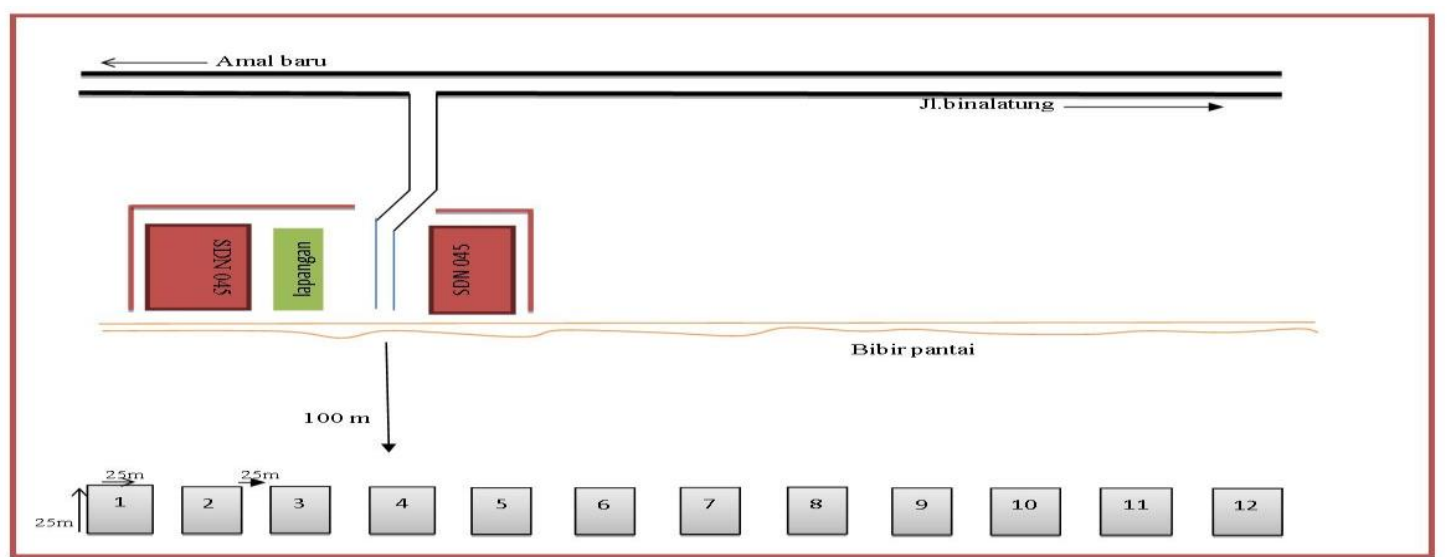

Gambar 4. Daerah pengambilan sampel

\section{Analisis data}

a. Bobot cangkang dan bobot berat kering daging dijumlahkan sehingga dapat dilakukan analisis data. Morfometri berhubungan dengan sifat pertumbuhan menggunakan rumus. Penentuan sifat pertumbuhan isometrik dan allometrik didasarkan dengan persamaan regresi dengan rumus (Gosling, 2002) yaitu : $Y=a X b$ atau $\log Y=\log a+b \log X$ Keterangan :
$\mathrm{Y}=$ berat jaringan /daging kerang kapah ( $M$. lyrata ; M. meretrix ; G. coaxans)

$X=$ dimensi cangkang (panjang, tinggi dan tebal dengan satuan $\mathrm{cm}$ )

$\mathrm{a}+\mathrm{b}=$ konstanta

Jika nilai $b=3$ maka bersifat isometric, nilai $b<2$ bersifat allometrik negative, nilai $b>$ 3 bersifat allometrik positif. Pertumbuhan bobot lebih dominan daripada pertumbuhan panjang berarti pertumbuhan kerang tersebut bersifat 
allometri positif. Pertumbuhan panjang lebih dominan daripada pertumbuhan berat kerang tersebut berarti pertumbuhan tersebut bersifat allometri negative. Pertumbuhan panjang seimbang dengan pertumbuhan berat berarti pertumbuhan tersebut bersifat isometric. Analisa dan pengolahan data dilakukan dengan cara memasukkan data panjang dan berat yang sudah diubah dalam bentuk Logaritma kemudian diolah dengan menggunakan "Software" Microsoft Excel 2010.

b. Untuk mengetahui hubungan panjang, tinggi dan tebal (dimensi cangkang) dan berat (berat jaringan) dilakukan perhitungan koefisien korelasi (Effendie, 1979). Hubungan panjang cangkang dan berat kering menggunakan data panjang dan berat kering daging pada kerang, Hubungan tinggi cangkang dan berat kering menggunakan data tinggi dan berat kering daging pada kerang, Hubungan tebal cangkang dan berat kering menggunakan data tebal dan berat kering daging pada kerang. Kriteria koefisien korelasi menurut (Sarwono, 2006) yaitu :
0 : Tidak ada korelasi antara dua variabel $>0-0,25$ : Korelasi sangat lemah

$>0,25-0,5:$ :Korelasi cukup

$>0,5-0,75$ : Korelasi kuat

$>0,75-0,99$ : Korelasi sangat kuat

1

: Korelasi sempurna

\section{Hasil dan Pembahasan}

Hasil sampel dalam penelitian didapatkan yaitu sampel kerang kapah jenis $M$. meretix adalah sebanyak 384 individu; jenis spesies $M$. lyrata adalah sebanyak 165 individu ; jenis spesies $G$. coaxans adalah sebanyak 58 individu. Hasil tersebut didapatkan dari 12 plot yang dibuat selama proses penelitian dengan luas plot $25 \times 25$ meter. Hasil penelitian tersebut di sajikan dalam Tabel 1 dibawah ini dan dalam diagram PIE untuk prosentase jenis kerang kapah (Gambar 5) sebagai berikut :

Tabel 1. Jumlah kerang kapah yang didapatkan dipantai Binalatung

\begin{tabular}{ccccc}
\hline No & Sampel & M. meretrix & M. lyrata & G. coaxans \\
\hline 1 & Plot 1 & 23 & 24 & 0 \\
2 & Plot 2 & 37 & 15 & 0 \\
3 & Plot 3 & 36 & 22 & 3 \\
4 & Plot 4 & 25 & 16 & 6 \\
5 & Plot 5 & 36 & 12 & 11 \\
6 & Plot 6 & 35 & 13 & 6 \\
7 & Plot 7 & 25 & 10 & 3 \\
8 & Plot 8 & 35 & 15 & 3 \\
9 & Plot 9 & 37 & 18 & 6 \\
10 & Plot 10 & 34 & 8 & 3 \\
11 & Plot 11 & 35 & 7 & 9 \\
12 & Plot 12 & 26 & 4 & 7 \\
\hline \multicolumn{7}{r}{} & Total & $\mathbf{3 8 4}$ & $\mathbf{1 6 5}$ & $\mathbf{5 8}$ \\
\hline
\end{tabular}

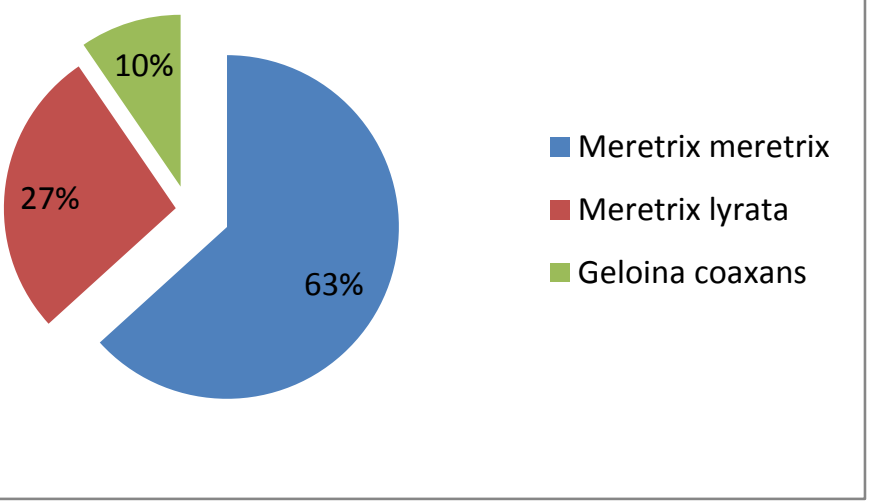

Gambar 5. Persentase berdasarkan jenis Spesies 


\section{Hubungan dimensi cangkang dan berat jaringan dari M. meretrix}

Hasil sampel yang diperoleh selama penelitian ditemukan jumlah sampel kerang kapah jenis M. meretix adalah sebanyak 384 spesies. Hasil tersebut didapatkan dari 12 plot yang dibuat selama proses penelitian dengan luas plot 25x 25 meter. Selanjutnya dilakukan proses pengukuran dan penimbangan kerang kapah yang telah di oven selama 2 jam dengan hasil seperti tabel dibawah ini :

\begin{tabular}{clllll}
\hline No & Pengukuran & Persamaan regresi & Sifat pertumbuhan & Korelasi & Keterangan \\
\hline 1 & Panjang & $y=3.0613 x-4.9368$ & Allometri positif & 0.8574 & Gambar 6 \\
2 & Tinggi & $y=3.0762 x-4.716$ & Allometri positif & 0.8520 & Gambar 7 \\
3 & Tebal & $y=2.7353 x-3.7139$ & Allometri negatif & 0.8479 & Gambar 8 \\
\hline
\end{tabular}

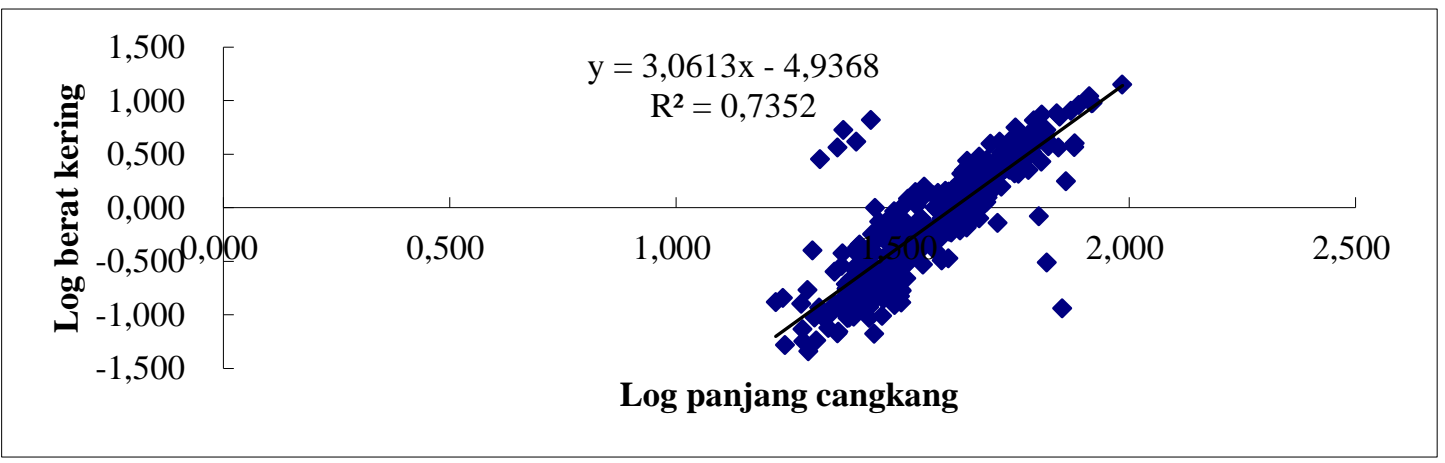

Gambar 6. Hubungan panjang cangkang dan berat kering daging M. meretrix

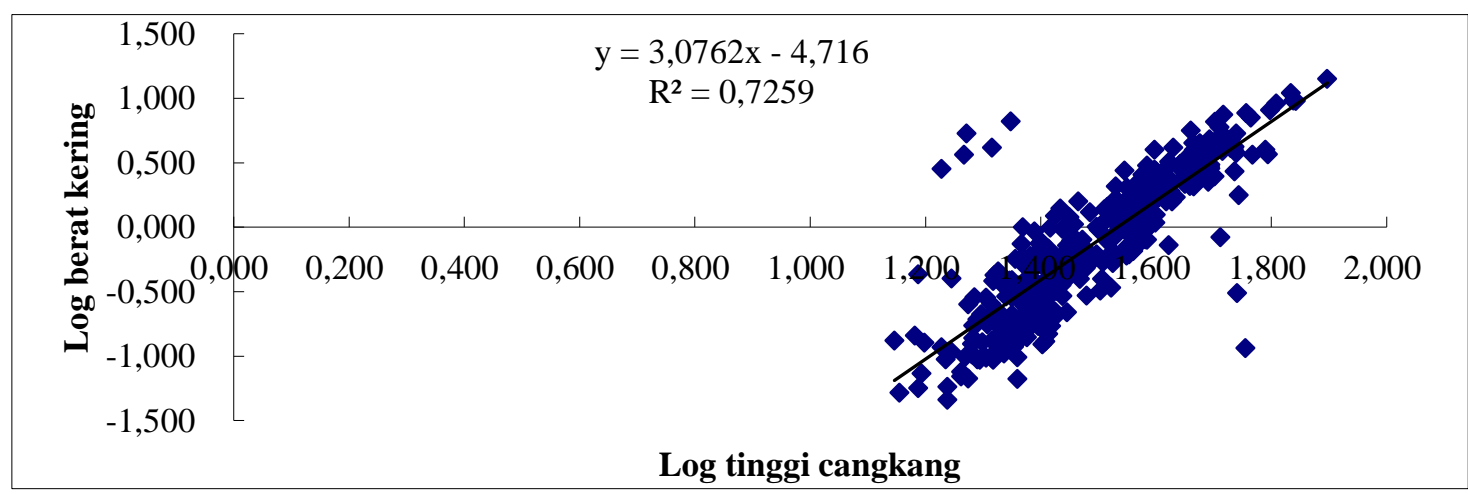

Gambar 7. Hubungan tinggi cangkang dan berat kering daging M. meretrix

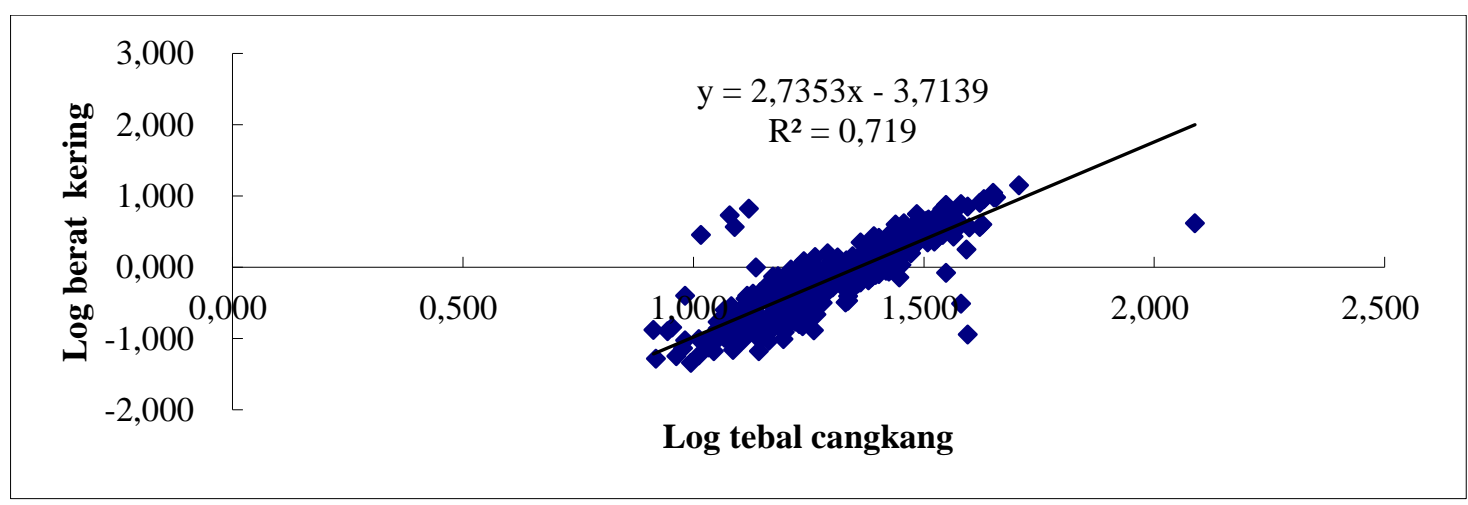

Gambar 8. Hubungan tebal cangkang dan berat kering daging M. meretrix 


\section{Hubungan dimensi cangkang dan berat jaringan M. lyrata}

Hasil sampel yang diperoleh selama penelitian ditemukan jumlah sampel kerang kapah jenis $M$. lyrata adalah sebanyak 165 spesies. Hasil tersebut didapatkan dari 12 plot yang dibuat selama proses penelitian dengan luas plot 25x 25 meter. Selanjutnya dilakukan proses pengukuran dan penimbangan kerang kapah yang telah dioven selama 2 jam dengan hasil seperti tabel dibawah ini :

\begin{tabular}{llllll}
\hline No & pengukuran & Persamaan regresi & Sifat pertumbuhan & korelasi & Keterangan \\
\hline 1 & Panjang & $y=3.3024 x-5.2966$ & Allometri positif & 0.8978 & Gambar 9 \\
2 & Tinggi & $y=3.4276 x-5.2024$ & Allometri positif & 0.8984 & Gambar 10 \\
3 & Tebal & $y=2.8327 x-3.8115$ & Allometri negatif & 0.8927 & Gambar 11 \\
\hline
\end{tabular}

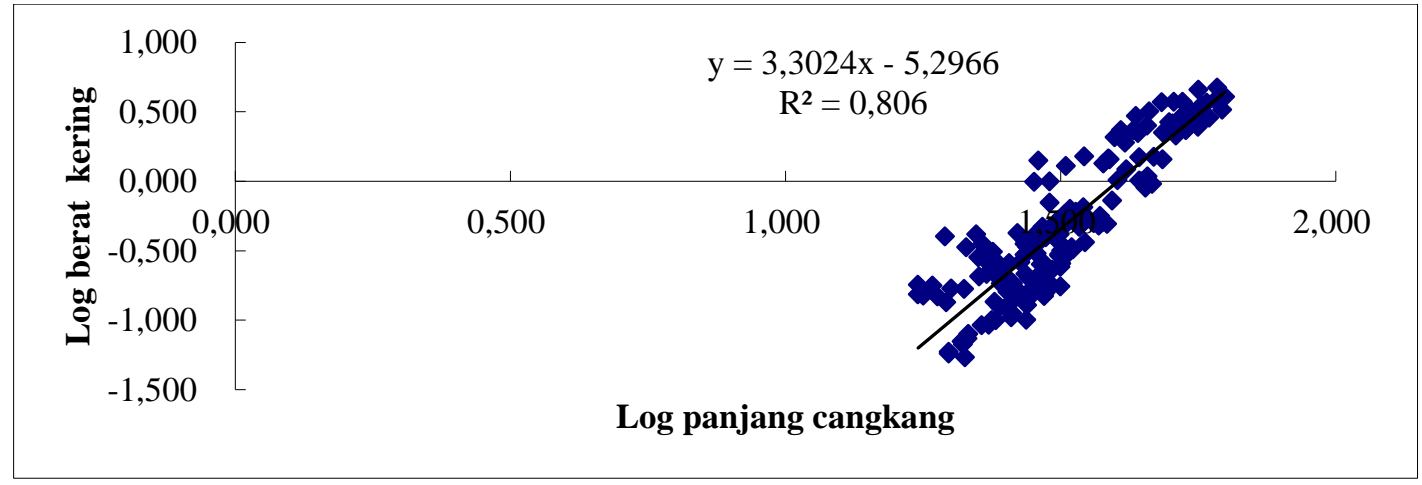

Gambar 9. Hubungan panjang cangkang dan berat kering daging M. lyrata

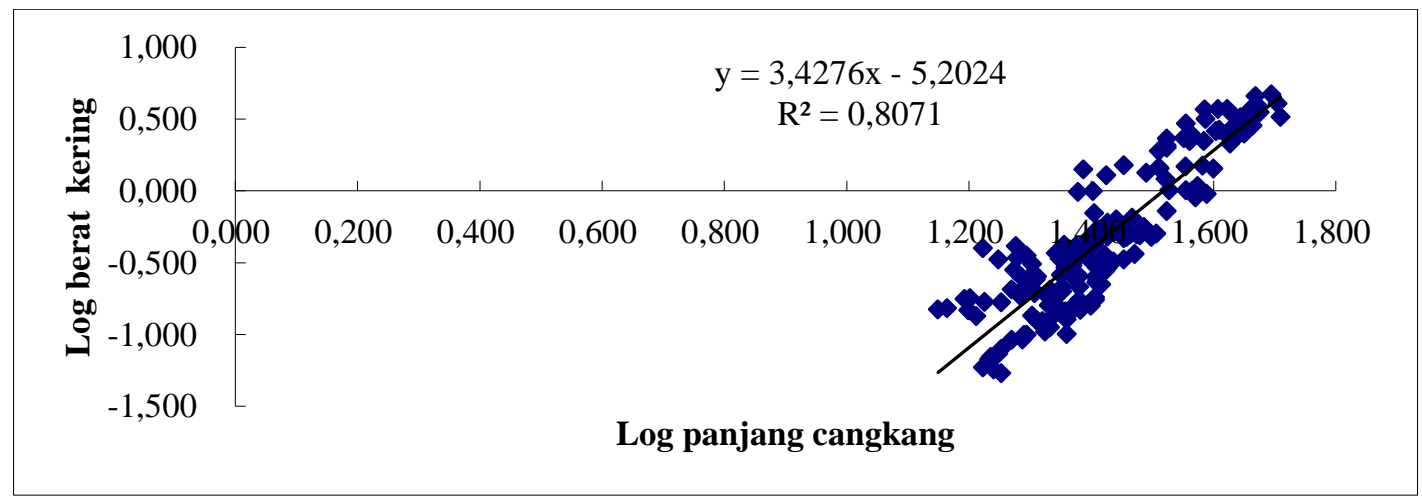

Gambar 10. Hubungan tinggi cangkang dan berat kering daging M. lyrata

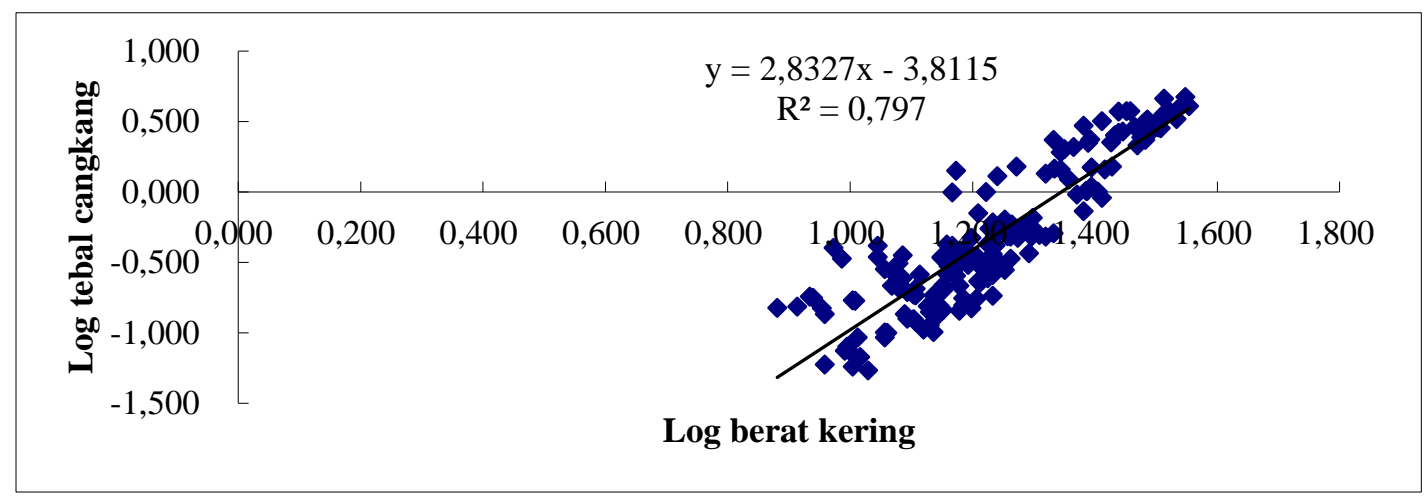

Gambar 11. Hubungan tebal cangkang dan berat kering daging M. lyrata 


\section{Hubungan dimensi cangkang dan berat} jaringan G. Coaxans

Hasil sampel yang diperoleh selama penelitian ditemukan jumlah sampel kerang kapah jenis G. coaxans adalah sebanyak 58 spesies. Hasil tersebut didapatkan dari 12 plot yang dibuat selama proses penelitian dengan luas plot 25x 25 meter. Selanjutnya dilakukan proses pengukuran dan penimbangan kerang kapah yang telah dioven selama 2 jam dengan hasil seperti tabel dibawah ini :

\begin{tabular}{llllll}
\hline No & pengukuran & Persamaan regresi & Sifat pertumbuhan & korelasi & Keterangan \\
\hline 1 & Panjang & $\mathrm{y}=3.5356 \mathrm{x}-5.705$ & Allometri positif & 0.9091 & Gambar 12 \\
2 & Tinggi & $\mathrm{y}=3.5983 \mathrm{x}-5.5891$ & Allometri positif & 0.9251 & Gambar 13 \\
3 & Tebal & $\mathrm{y}=2.9841 \mathrm{x}-4.1839$ & Allometri negatif & 0.9136 & Gambar 14 \\
\hline
\end{tabular}

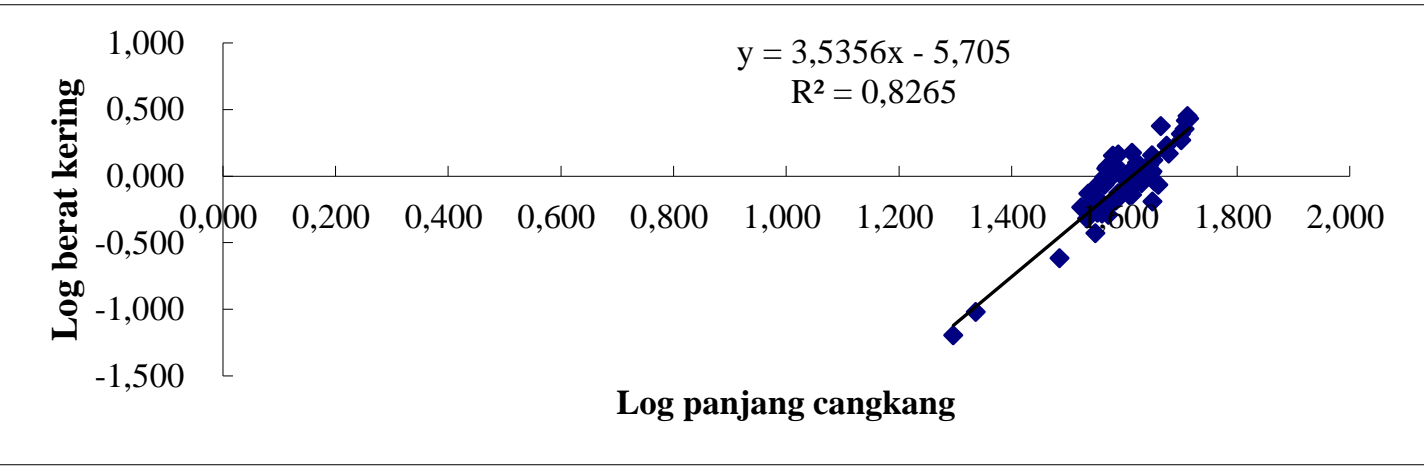

Gambar 12. Hubungan panjang cangkang dan berat kering daging G. coaxans

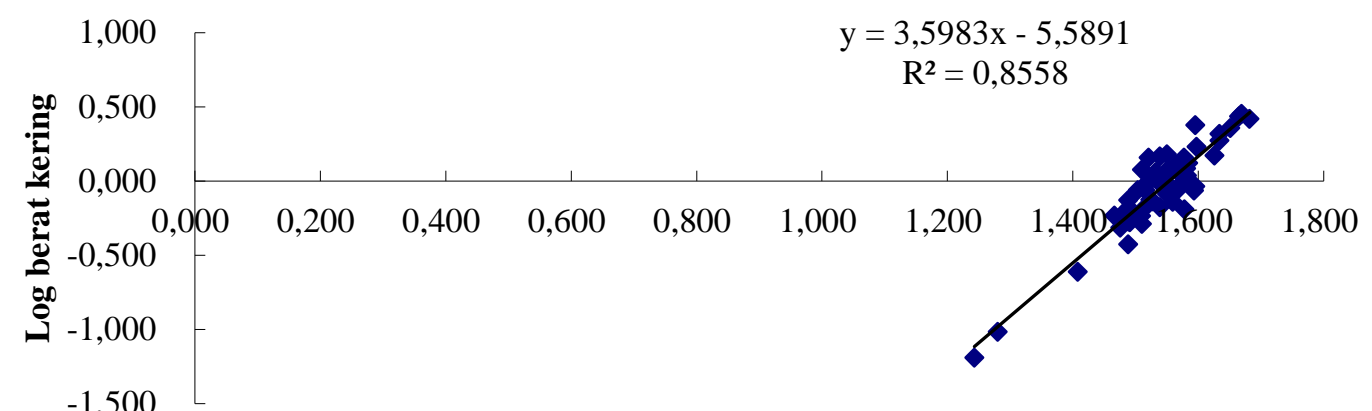

Log tinggi cangkang

Gambar 13. Hubungan tinggi cangkang dan berat kering daging G. coaxans

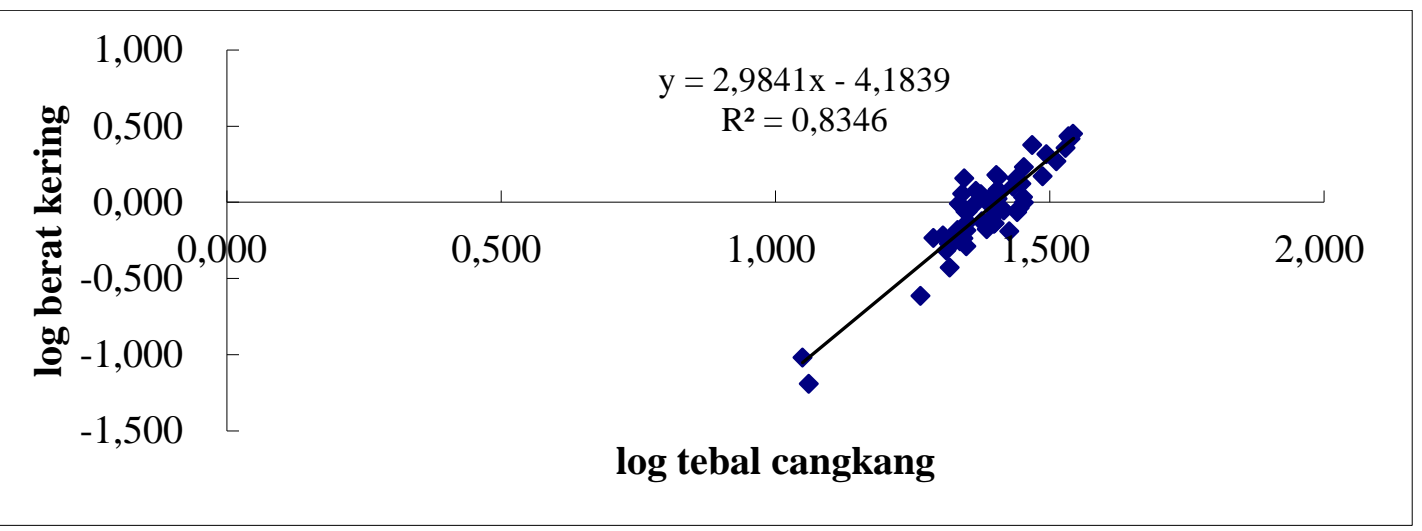

Gambar 14. Hubungan tebal cangkang dan berat kering daging G. coaxans 
Tabel 2. Perbandingan Pertumbuhan Kerang

\begin{tabular}{|c|c|c|c|c|c|c|}
\hline \multirow{2}{*}{$\begin{array}{c}\text { Lokasi } \\
\text { Penelitian }\end{array}$} & \multirow[t]{2}{*}{ Tahun } & \multirow[t]{2}{*}{ Spesies } & \multicolumn{3}{|c|}{ Pertumbuhan } & \multirow{2}{*}{$\begin{array}{l}\text { Source / } \\
\text { Literatur }\end{array}$} \\
\hline & & & $\begin{array}{l}\text { Panjang } \\
\text { cangkang } \\
\text { + Berat } \\
\text { Daging }\end{array}$ & $\begin{array}{c}\text { Tinggi } \\
\text { Cangkan } \\
\text { g + Berat } \\
\text { Daging }\end{array}$ & $\begin{array}{c}\text { Tebal } \\
\text { Cangkan } \\
\text { g + Berat } \\
\text { Daging }\end{array}$ & \\
\hline $\begin{array}{l}\text { Binalatung } \\
\text { Kota Tarakan, } \\
\text { Indonesia }\end{array}$ & 2015 & M. meretrix & $\begin{array}{l}\text { Allometri } \\
\text { Positif }\end{array}$ & $\begin{array}{l}\text { Allometri } \\
\text { Positif }\end{array}$ & $\begin{array}{l}\text { Allometri } \\
\text { Negatif }\end{array}$ & This Study \\
\hline $\begin{array}{l}\text { Binalatung } \\
\text { Kota Tarakan, } \\
\text { Indonesia }\end{array}$ & 2015 & M. lyrata & $\begin{array}{l}\text { Allometri } \\
\text { Positif }\end{array}$ & $\begin{array}{l}\text { Allometri } \\
\text { Positif }\end{array}$ & $\begin{array}{l}\text { Allometri } \\
\text { Negatif }\end{array}$ & This Sutdy \\
\hline $\begin{array}{l}\text { Binalatung } \\
\text { Kota Tarakan, } \\
\text { Indonesia }\end{array}$ & 2015 & G. coaxans & $\begin{array}{l}\text { Allometri } \\
\text { Positif }\end{array}$ & $\begin{array}{l}\text { Allometri } \\
\text { Positif }\end{array}$ & $\begin{array}{l}\text { Allometri } \\
\text { Negatif }\end{array}$ & This Study \\
\hline $\begin{array}{l}\text { KKMB Kota } \\
\text { Tarakan, } \\
\text { Indonesia }\end{array}$ & 2012 & G. coaxans & $\begin{array}{l}\text { Allometri } \\
\text { Positif }\end{array}$ & $\begin{array}{l}\text { Allometri } \\
\text { Positif }\end{array}$ & $\begin{array}{l}\text { Allometri } \\
\text { Negatif }\end{array}$ & $\begin{array}{l}\text { Wiharyanto dan } \\
\text { Salim (2012) }\end{array}$ \\
\hline $\begin{array}{l}\text { Pantai Amal } \\
\text { Lama Kota } \\
\text { Tarakan, } \\
\text { Indonesia }\end{array}$ & $\begin{array}{l}\text { November } \\
2011\end{array}$ & M. meretrix & $\begin{array}{l}\text { Allometri } \\
\text { Positif }\end{array}$ & $\begin{array}{l}\text { Allometri } \\
\text { Positif }\end{array}$ & $\begin{array}{l}\text { Allometri } \\
\text { Positif }\end{array}$ & $\begin{array}{l}\text { Salim dan } \\
\text { Firdaus (2012) }\end{array}$ \\
\hline $\begin{array}{l}\text { Pantai Amal } \\
\text { Lama Kota } \\
\text { Tarakan, } \\
\text { Indonesia }\end{array}$ & $\begin{array}{l}\text { Desember } \\
2011\end{array}$ & M. meretrix & $\begin{array}{l}\text { Allometri } \\
\text { Positif }\end{array}$ & $\begin{array}{l}\text { Allometri } \\
\text { Positif }\end{array}$ & $\begin{array}{l}\text { Allometri } \\
\text { Positif }\end{array}$ & $\begin{array}{l}\text { Salim dan } \\
\text { Firdaus (2012) }\end{array}$ \\
\hline $\begin{array}{l}\text { Pantai Amal } \\
\text { Lama Kota } \\
\text { Tarakan, } \\
\text { Indonesia }\end{array}$ & $\begin{array}{l}\text { Januari } \\
2012\end{array}$ & M. meretrix & $\begin{array}{l}\text { Allometri } \\
\text { Negatif }\end{array}$ & $\begin{array}{l}\text { Allometri } \\
\text { Negatif }\end{array}$ & $\begin{array}{l}\text { Allometri } \\
\text { Negatif }\end{array}$ & $\begin{array}{l}\text { Salim dan } \\
\text { Firdaus (2012) }\end{array}$ \\
\hline $\begin{array}{l}\text { Pantai Amal } \\
\text { Lama, Kota } \\
\text { Tarakan, } \\
\text { Indonesia }\end{array}$ & 2012 & M. lyrata & $\begin{array}{l}\text { Allometri } \\
\text { Positif }\end{array}$ & $\begin{array}{l}\text { Allometri } \\
\text { Positif }\end{array}$ & $\begin{array}{l}\text { Allometri } \\
\text { Positif }\end{array}$ & $\begin{array}{l}\text { Herliantos et al } \\
\text { (2012) }\end{array}$ \\
\hline $\begin{array}{l}\text { Pantai Amal } \\
\text { Baru, Kota } \\
\text { Tarakan, } \\
\text { Indonesia }\end{array}$ & 2012 & M. lyrata & $\begin{array}{l}\text { Allometri } \\
\text { Positif }\end{array}$ & $\begin{array}{l}\text { Allometri } \\
\text { Positif }\end{array}$ & $\begin{array}{l}\text { Allometri } \\
\text { Negatif }\end{array}$ & $\begin{array}{l}\text { Herliantos et al } \\
\text { (2012) }\end{array}$ \\
\hline $\begin{array}{l}\text { Pantai } \\
\text { Binalatung, } \\
\text { Kota Tarakan, } \\
\text { Indonesia }\end{array}$ & 2012 & M. lyrata & $\begin{array}{l}\text { Allometri } \\
\text { Positif }\end{array}$ & $\begin{array}{l}\text { Allometri } \\
\text { Positif }\end{array}$ & $\begin{array}{l}\text { Allometri } \\
\text { Positif }\end{array}$ & $\begin{array}{l}\text { Herliantos et al } \\
\text { (2012) }\end{array}$ \\
\hline $\begin{array}{l}\text { Iwahig, } \\
\text { Palawan, } \\
\text { Philippines }\end{array}$ & 2014 & $\begin{array}{l}\text { Polymesoda } \\
\text { erosa }\end{array}$ & $\begin{array}{l}\text { Allometri } \\
\text { Negatif }\end{array}$ & - & - & $\begin{array}{l}\text { Dolorosa and } \\
\text { Galon (2014) }\end{array}$ \\
\hline $\begin{array}{l}\text { South West } \\
\text { Coast, India }\end{array}$ & 2013 & M. casta & $\begin{array}{l}\text { Allometri } \\
\text { Positif }\end{array}$ & - & - & $\begin{array}{l}\text { Laxmilatha } \\
\text { (2013) }\end{array}$ \\
\hline $\begin{array}{l}\text { Cross River, } \\
\text { Nigeria }\end{array}$ & 2013 & $\begin{array}{l}\text { Tympanotonus } \\
\text { fuscatus }\end{array}$ & $\begin{array}{l}\text { Allometri } \\
\text { Negatif }\end{array}$ & - & - & Udo (2013) \\
\hline $\begin{array}{l}\text { Southeastern } \\
\text { coast of } \\
\text { Bangladesh }\end{array}$ & 2007 & $\begin{array}{l}\text { Crassostrea } \\
\text { madrasensis }\end{array}$ & $\begin{array}{l}\text { Allometri } \\
\text { Negatif }\end{array}$ & - & - & $\begin{array}{l}\text { Nurul Amin et } \\
\text { al (2008) }\end{array}$ \\
\hline $\begin{array}{l}\text { Mumbai } \\
\text { Waters, India }\end{array}$ & 2005 & M. meretrix & $\begin{array}{l}\text { Allometri } \\
\text { Negatif }\end{array}$ & - & - & $\begin{array}{l}\text { Sharma et al } \\
(2005)\end{array}$ \\
\hline $\begin{array}{l}\text { Mumbai } \\
\text { Waters, India }\end{array}$ & 2005 & Perna viridis & $\begin{array}{l}\text { Allometri } \\
\text { Negatif }\end{array}$ & - & - & $\begin{array}{l}\text { Sharma et al } \\
(2005)\end{array}$ \\
\hline
\end{tabular}




\section{Kesimpulan}

Hasil penelitian mengenai kerang kapah di daerah pantai Binalatung kota Tarakan didapatkan tiga jenis spesies yaitu M.meretrix dengan persentase $63 \%$, M. lyrata dengan persentase 27\%, G.coaxans dengan persentase sebesar $10 \%$.

Pertumbuhan dari kerang kapah terdapat tiga jenis yaitu pertumbuhan antara panjang cangkang dan berat daging ; pertumbuhan antara tinggi cangkang dan berat daging ; pertumbuhan antara tebal cangkang dan berat daging.

Pertumbuhan antara panjang cangkang dan berat daging dan pertumbuhan antara tinggi cangkang dan berat daging untuk jenis M.meretrix, M.lyrata, G.coaxans bersifat allometri positif dengan penjelasan bahwa pertumbuhan panjang cangkang lebih lambat dibandingkan dengan pertumbuhan berat daging (bentuk tubuh gemuk).

Pertumbuhan antara tinggi cangkang dan berat daging untuk jenis M.meretrix, M.lyrata, G.coaxans bersifat allometri negatif. Pertumbuhan antara tinggi cangkang dan berat daging untuk jenis M.meretrix, M.lyrata, G.coaxans bersifat allometri negatif.

\section{Daftar Pustaka}

Gosling, E. 2002. Bivalve Molluscs, Biology, Ecology and Culture. Fishing News Books. Blackwell Publishing, UK: 443 p.

Herliantos., Brian, B.S., Rosmianto., Salim, G. 2012. Pengukuran Morfometri Kerang Kapah (Meretrix lyrata) Di Pantai Amal Lama Kota Tarakan. Jurnal Harpodon Borneo. 5 (2) ; 9 - 103.

Laxmilatha, P. 2013. Population dynamics of the edible clam Meretrix casta (Chemnitz) (International Union for Conservation of Nature Status : Vulnerable) From two estuaries of North Kerala, South west Coast of India. International Journal of Fisheries and Aquaculture 5 (10): 253-261.

Udo, P.J. 2013. Length- Weiht/Girth Relationship and Condition Factor of the Periwinkle Tympanotonus fuscatus (Cerithidae : Gastropoda) of The Cross River, Nigeria. International Journal of Fisheries and Aquatic Studies 1 (1) : 26 $-28$.
Sharma, R., Venkateshvaran, K., Purushothaman, C.S. 2005 LengtWeight Relationship and Condition Factor of Perna Viridis (Linnaeus, 1758) AND Meretrix Meretrix (Linneaeus, 1758) From Mumbai Waters. Journal Indian Fisheries Association 32. 157163.

Dolorosa, R.G., Galon, F-D. 2014. Population dynamics of the mangrove clam Polymesoda erosa (Bivalvia : Corbiculidae) in Iwahig, Palawan, Philippines. Internasional Journal of Fauna and Biological Studies. 1 (6) : 1115.

Salim, G., Firdaus, M. 2012. Kajian Bioteknis mengenai potensi, pertumbuhan, indeks kondisi kerang kapah (Meretrix meretrix) dari hasil tangkapan pengepul Pantai amal lama kota Tarakan. Penelitian Mandiri Dosen. Tidak di publikasikan. Fakultas Perikanan dan IImu Kelautan. Universitas Borneo Tarakan. 476 Halaman.

Salim, G., Firdaus, M. 2012. Kajian Pertumbuhan Absolut dan Allometri Kerang Kapah (Meretrix meretrix) Yang Berasal Dari Pengepul di Pantai Amal Lama Pulau Tarakan. Seminar Nasional Tahunan IX Hasil Penelitian Perikanan dan Kelautan Biologi Perikanan (BP-13). 1-9.

Amin, S.M.N., Zafar, M., Halim, A. 2008. Age, growth, mortality and population structure of the oyster Crassostrea madrasensis in the Moheskhali Channel (Southeastern coast of Bangladesh. Journal Applied Ichthyology 24 (1). 1825.

Wiharyanto, D., Salim, G. 2012. Analisis Korelasi Populasi Biota Endemik Kerang Kapah (Geloina Coaxans) dan Vegetasi Mangrove di Kawasan Konservasi mangrove dan Bekantan Kota Tarakan. Desiminasi Hasil Penelitian Hibah Bantuan Sosial Pemerintah Kota Tarakan. 278 halaman.

Wilbur, K., Owen, G. 1964. Physiology of Mollusca. Vol 1. Academic press. New york. 211- 242 pp. 